\title{
THE IMPACTS OF THE MIDDLE HOLOCENE HIGH SEA-LEVEL STAND AND CLIMATIC CHANGES ON MANGROVES OF THE JUCURUÇU RIVER, SOUTHERN BAHIA - NORTHEASTERN BRAZIL
}

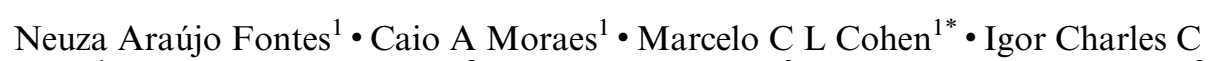
Alves $^{1} \bullet$ Marlon Carlos França ${ }^{2} \cdot$ Luiz C R Pessenda $^{3} \bullet$ Mariah Izar Francisquini $^{3} \bullet$ José Albertino Bendassolli $^{4}$ Kita Macario $^{5} \cdot$ Francis Mayle $^{6}$

${ }^{1}$ Graduate Program of Geology and Geochemistry, Federal University of Pará. Rua Augusto Corrêa, 01 - Guamá. CEP 66075-110, Belém (PA), Brazil.

${ }^{2}$ Federal Institute of Pará, Av. Alm. Barroso, 1155, Marco, 66090-020, Belém (PA), Brazil.

${ }^{3}$ University of São Paulo, CENA $/{ }^{14} \mathrm{C}$ Laboratory, Av. Centenário 303, 13400-000, Piracicaba, São Paulo, Brazil.

${ }^{4}$ University of São Paulo, CENA/Stable Isotopes Laboratory, Av. Centenário 303, 13400-000, Piracicaba, São Paulo.

${ }^{5}$ LAC-UFF AMS Laboratory-Fluminense Federal University, Physics Department, Niteroi, Rio de Janeiro, Brazil.

${ }^{6}$ Centre for Past Climate Change and Department of Geography \& Environmental Science, School of Archaeology, Geography and Environmental Science (SAGES), University of Reading, Whiteknights, PO Box 227, Reading RG6 6AB, United Kingdom.

\begin{abstract}
The aim of this paper is to evaluate the compatibility between the Holocene relative sea-level (RSL) curves proposed for the Brazilian littoral and mangrove dynamics along a fluvial valley in the state of southern Bahia. This was done integrating geomorphological, sedimentological, palynological, and stable isotopic data from two cores collected at the mouth of the Jucuruçu River and at a site $23 \mathrm{~km}$ inland, near the city of Prado, northeastern Brazil. Core PR07, sampled from a fluvial plain at about $4.5 \pm 1 \mathrm{~m}$ above the RSL, reveals mangrove pollen (5-20\%) and estuarine/terrestrial organic matter $\left(\delta^{13} \mathrm{C}=\sim-25 \%, \mathrm{C} / \mathrm{N}=7.3-67\right)$ between $4.5 \mathrm{~m}(\sim 7400 \mathrm{cal}$ yr BP$)$ and $1.75 \mathrm{~m}$ depth ( $\sim 5350 \mathrm{cal}$ yr BP). Core PR11, sampled from a mangrove tidal flat, also revealed mangrove pollen taxa $(5-28 \%)$ since $660 \mathrm{cal}$ yr BP. Core PR07 indicated absence of mangrove pollen and increase of sedimentary organic matter sourced from terrestrial $\mathrm{C} 3$ plants $\left(\delta^{13} \mathrm{C}=\sim-27 \%\right.$ o, $\left.\mathrm{C} / \mathrm{N}=22-159\right)$ during the last $5350 \mathrm{cal}$ yr BP. Probably, the changes in vegetation and sedimentary organic matter identified in core PR07 were caused by the combined effects of the RSL fluctuations, with a highstand at about $5350 \mathrm{cal}$ yr BP of $2.7 \pm 1.35 \mathrm{~m}$, and changes in fluvial discharge.
\end{abstract}

KEYWORDS: carbon and nitrogen isotopes, climate changes, Holocene, mangrove, palynology, sea level.

\section{INTRODUCTION}

Relative sea level (RSL) fluctuations and climate changes have caused significant impacts on mangroves, since the development of this wetland is influenced by complex interactions involving gradients of tidal flooding frequency, nutrient availability, sediment salt concentration across the intertidal area, and input of sediment and freshwater (Krauss et al. 2008; Alongi 2015). This ecosystem is highly adaptive, with plants tolerant to extreme environmental conditions (Liang et al. 2008). This adaptability has allowed mangroves to withstand environmental changes throughout the Holocene (Monacci et al. 2009) and become a marker of great importance for scientific analysis of coastal change (Blasco et al.1996).

Consider the northern Brazilian littoral, climatic, and sea-level changes that have controlled the Amazon coast wetlands, leading to the formation of a marine-influenced littoral, submitted to tidal water salinity between $30 \%$ and $7 \%$ and dominated by mangroves and salt-marsh vegetation, and a fluvial sector, close to the Amazon River mouth, with tidal water salinity below 7\%o, characterized by várzea and herbaceous (Cohen et al. 2012). A study based on the mineral composition and foraminifera in the Rio Grande do Norte coast, $\sim 1500 \mathrm{~km}$ north of the study site, revealed that an accelerated sea-level rise $\left(6.1 \mathrm{~mm} / \mathrm{yr}^{-1}\right.$, between 8300 and 7000 cal yr BP) combined with geomorphological confinement of the intertidal zone was probably responsible for the demise of mangrove vegetation, which thrived again in the late Holocene (Boski et al. 2015).

\footnotetext{
*Corresponding author. Email: mcohen80@hotmail.com.
} 


\section{$216 \quad N$ A Fontes et al.}

Regarding the Linhares littoral-Espírito Santo, $350 \mathrm{~km}$ south of the study site, coastal morphologic features are associated to regressions, transgressions, and sea-level highstands (Rossetti et al. 2015). A coastal progradation, caused by the sea-level fall before and during the Last Glacial Maximum, produced beach ridges and deltaic deposits. They were partly reworked during the post-glacial sea-level rise. This event reached far westward and even crossed the paleoshoreline, ultimately reactivating estuaries previously abandoned over the Barreiras Formation in the continental area. These estuaries displayed sedimentary records indicating brackish conditions and expansion of mangroves up to the mid-Holocene, when these water bodies gradually became completely continental-influenced (Cohen et al. 2014; França et al. 2015; Rossetti et al. 2015).

The integration of these studies suggests that the mangrove dynamics along northern Brazil has been controlled mainly by the climate and RSL changes (Cohen et al. 2012). However, in southeastern Brazil, the displacement of mangroves would be mainly related to RSL changes and sediment transport (Pessenda et al. 2012; Cohen et al. 2014).

Holocene sea-level change along the Brazilian littoral is still an issue open to debate. Studies reveal that after the post-glacial sea-level rise, the RSL reached the current level between 7800 and $6600 \mathrm{cal} \mathrm{yr} \mathrm{BP}$, with different proposals of middle Holocene highstand $(1-5 \mathrm{~m})$ at about 5500 cal BP in northeastern and southeastern Brazil (Martin et al. 2003; Angulo et al. 2006; Caldas et al. 2006; Suguio et al. 2013; Castro et al. 2014 ). The RSL may have continuously decreased during the late Holocene (Angulo et al. 2006) or may have undergone oscillations (Martin 2003; Suguio et al. 2013). Along the northern Brazilian coast, the RSL reached its current level in the middle Holocene (Cohen et al. 2012), and it has remained stable since then. Then, the northeastern Brazilian coast should exhibit a transition between the maximum RSL $(+5 \mathrm{~m})$ of the southeastern Brazil (e.g. Angulo et al. 2006) and the stable RSL $(0 \mathrm{~m})$ of the northern Brazil (Cohen et al. 2005) since the middle Holocene. Depending on the amplitude of the Holocene sea level changes along the northeastern Brazilian littoral, the mangroves from Bahia (between northeastern and southeastern Brazil) should react to these RSL changes by a significant mangrove migration during the Holocene, following the topographic gradient.

Noteworthy is the fact that along the northeast Brazilian littoral, between Bahia and Maranhão with $\sim 2900 \mathrm{~km}$ of coastline, there is so far no evidence of impacts of the middle Holocene marine transgression and climate changes on vegetation $23 \mathrm{~km}$ from the coast (Figure 1). In addition, paleoenvironmental reconstructions based on sedimentary features, palynology, and $\delta^{13} \mathrm{C}$, $\delta^{15} \mathrm{~N}, \mathrm{C} / \mathrm{N}$ analysis have not been developed along the northeastern Brazilian coast. Therefore, the response of mangrove ecosystems to Holocene sea-level changes and climate changes remains poorly understood along this Brazilian coastal sector.

In order to confront the RSL curves, mainly based on dating of mollusk shells and vermetids, with the Holocene mangrove dynamics along the Jucuruçu River, Bahia State, northeastern Brazil, two sediment cores were sampled from a flood plain and a tidal plain. They are positioned $4.5 \pm 1 \mathrm{~m}$ above the modern RSL, which can record the RSL peak in the mid-Holocene, and $0.35 \mathrm{~m}$ above the RSL, which can record the recent mangrove establishment. They are located approximately $23 \mathrm{~km}$ and $200 \mathrm{~m}$ from the present-day Atlantic coast, respectively. This study is based on sedimentary features, pollen data, isotope analysis, and radiocarbon $\left({ }^{14} \mathrm{C}\right)$ dating, as well as LANDSAT imaging and SRTM data.

This study, based on this multi-proxy analysis, besides establishing a range for the Holocene RSL changes on the study coast, has the potential to contribute to discussions about the 


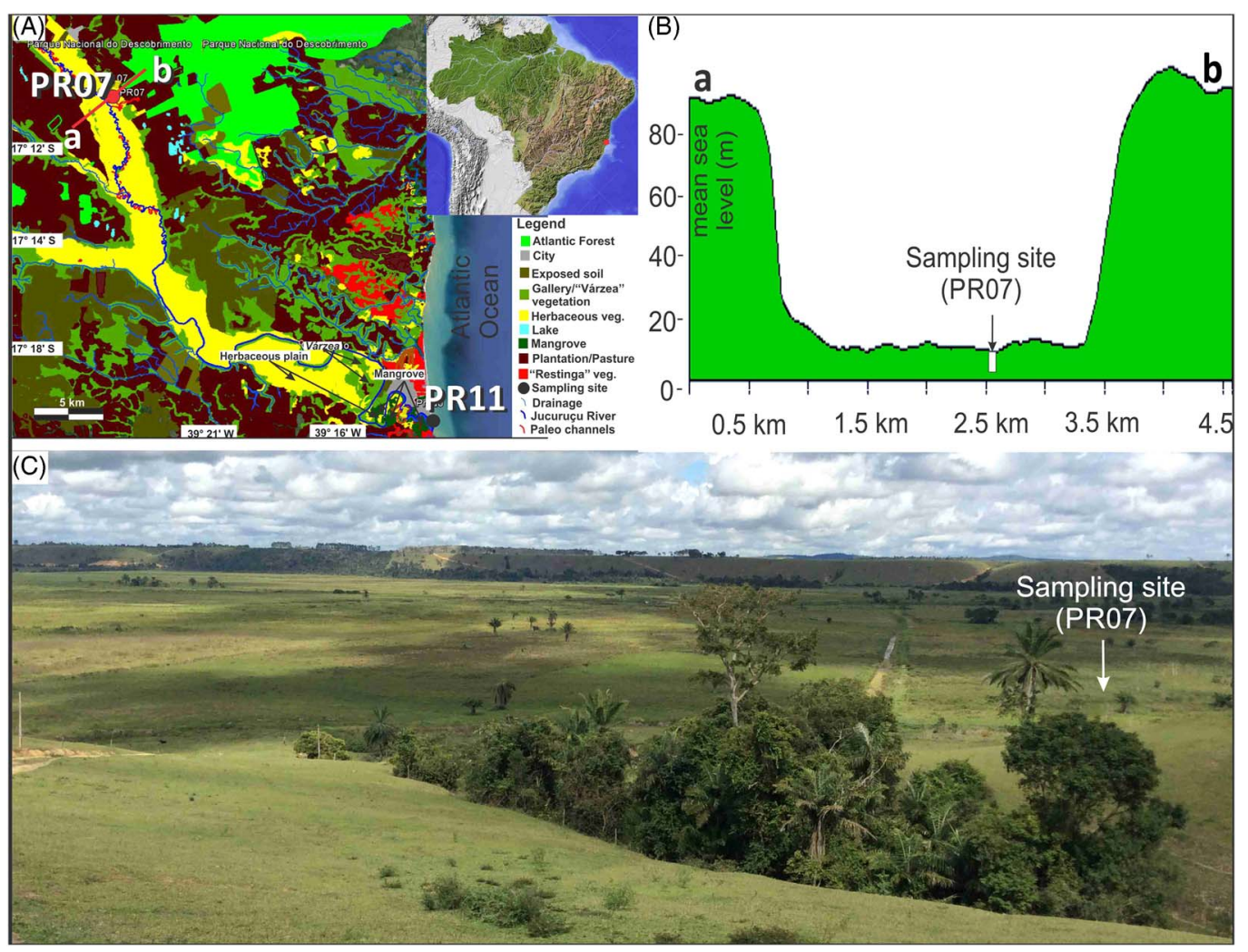

Figure 1 (A) Location of the sampling sites on vegetation map showing geomorphological features. (B) Topographic profile of the study site PR07. (C) Photography of the studied fluvial valley and sampling site PR07.

influence of river discharge (climate) and the sea-level changes component on the depositional environment and wetlands along the Brazilian coast, where a gradient of influence of fluvial discharge and RSL changes may be occurring. In addition, the assessment of mangrove dynamics along the Brazilian coast according to sea-level fluctuations and climate change during the Holocene is important for the projections about mangrove dispersals under future scenarios (Record et al. 2013) with accelerated sea-level rise rates, between 1.8 and $2.4 \mathrm{~mm} / \mathrm{yr}$, up to the end of this century (Church et al. 2013).

\section{STUDY AREA}

The study sites are located along the valley floodplain of the Jucuruçu River (Figures 1a-d). The study site has a tidal range of $2 \mathrm{~m}$ (DHN 2014) and is located adjacent to the Parque Nacional do Descobrimento (PND) near the coastal town of Prado, southern Bahia, Brazil (Figure 1). The region is characterized by a warm and humid tropical climate with annual precipitation and temperature averaging $1350 \mathrm{~mm}$ and $24.5^{\circ} \mathrm{C}$, respectively (Martorano and Coutinho 2003). The PND is a natural reserve with the original vegetation of the humid evergreen tropical rainforest (Atlantic Forest), where the most representative plant families are Fabaceae, Annonaceae, Myrtaceae, Sapotaceae, Mimosaceae, Moraceae, Melastomataceae, Arecaceae, Bignoniaceae, Lauraceae, Malpighiaceae, Lecythidaceae, Anacardiaceae, Euphorbiaceae, and Apocynaceae (Peixoto and Gentry 1990; Lima et al. 2002). 


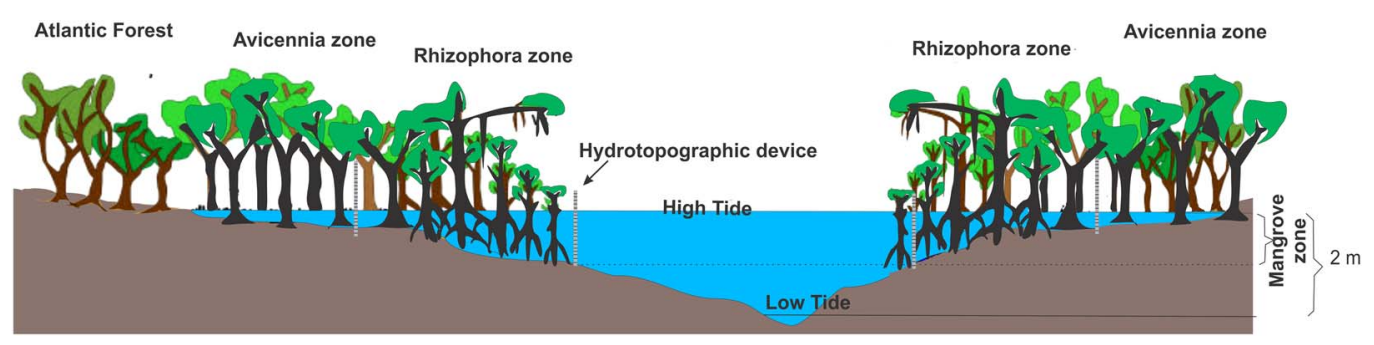

Figure 2 Devices for measuring the mangrove topographic distribution according to high and low tide levels.

\section{MATERIALS AND METHODS}

\section{Field Work and Sampling Processing}

A LANDSAT image acquired in July 2011 was obtained from the National Institute of Space Research, Brazil (INPE). A three-color-band composition (RGB 543) image was created and processed using the SPRING 3.6.03 image-processing system to discriminate different vegetation types and geomorphological features. The fieldwork was carried out in September 2013 and August 2014 and 2015. Sediment cores PR 07 (S 1708'47.7", W 39²5'19.21") and PR 11 (S 17²0'58.13", W 39²1'58.49") were taken from the river floodplain and tidal plain, dominated by herbaceous vegetation and mangrove, respectively, using a Russian Sampler. According to Shuttle Radar Topography Mission (SRTM) data and local hydrotopographic study (Figure 2), cores PR07 and PR11 are located $4.5 \pm 1 \mathrm{~m}$ and $0.35 \mathrm{~m}$ above the RSL, and located approximately $23 \mathrm{~km}(0.5 \mathrm{~km}$ from the Jucuruçu River) and $200 \mathrm{~m}$ from the present-day coast, respectively.

\section{Topographic Data}

Topographic data were derived from SRTM-30 data, downloaded from the USGS Seamless Data Distribution System. Image interpretation of elevation data was carried out using the software Global Mapper 12. The SRTM data from Marajó Island, northern Brazil, compared with local topographical measurements obtained by ground penetrating radar (GPR) georeferenced by satellite with vertical error of $16 \mathrm{~cm}$ have revealed an vertical error of $\sim 1 \mathrm{~m}$ for the SRTM data (Rossetti et al. 2007; Mantelli et al. 2009). Considering the floodplain of the Jucuruçu River, which exhibits a smooth topographical gradient along the studied fluvial valley, and the hydrotopographic measures obtained during the field work (see details below), we presumed that the vertical error of the presented SRTM data is $\sim 1 \mathrm{~m}$.

In order to identify the paleo sea level we used as reference the present level of occurrence of the modern mangrove, and to identify topographic intervals colonized by modern mangroves, hydrotopographic devices (gauges) were installed at 10 points along a tidal channel (Figure 2) to measure the maximal high-tide elevations in zones occupied by mangroves. Tidal water levels at the respective points were referred and adjusted to tide chart data (DHN 2014). The margin of error is $\sim 1 \mathrm{~cm}$. A similar methodological approach was undertaken in the littoral zone of northern Brazil (Cohen and Lara 2003).

\section{Facies Description}

The cores were X-rayed to identify sedimentary structures. Bulk samples $(0.5 \mathrm{~g}$ each) were selected at $5-\mathrm{cm}$ intervals for grain size analysis at the Chemical Oceanography Laboratory of 
the Federal University of Pará (UFPA), using a laser particle-size analyzer (SHIMADZU SALD 2101, see Franca et al. [2013] for details about sample preparation). Following the methods of Walker (1992), facies analysis was undertaken, including description of color, lithology, texture, and structure. The sedimentary facies were codified following Miall (1978). The studied stratigraphic profile was divided into facies associations, whereby sedimentary units are used to define a particular sedimentary environment (Reading 1996).

\section{Palynological Analysis}

Sixty-nine $1-\mathrm{cm}^{3}$ samples were taken at $12-\mathrm{cm}$ and 5-cm intervals through cores PR07 and PR11 for pollen analysis, respectively. All samples were prepared using standard pollen analytical techniques, including acetolysis (Erdtman 1960). Pollen and spores were identified by comparison with reference collections of various pollen keys (e.g. Roubik and Moreno 1991), reference collection of the Laboratory of Coastal Dynamics, (LADIC-UFPA), and the ${ }^{14} \mathrm{C}$ Laboratory of the Center for Nuclear Energy in Agriculture (CENA/USP). A minimum of 300 terrestrial pollen grains were counted for each sample. Pollen and spore data were presented in pollen diagrams as percentages of the total terrestrial pollen sum. The taxa were grouped according to source: mangroves, trees and shrubs, palms, herbs, and ferns. The software programs TILIA and TILIAGRAF were used for calculation and to plot the pollen diagram (Grimm 1987).

\section{Isotopic and Chemical Analysis}

A total of 91 samples $(50-60 \mathrm{mg})$ were collected at 5-cm intervals from the sediment core. Sediments were treated with $4 \% \mathrm{HCl}$ to eliminate carbonate, and added distilled water until the $\mathrm{pH}$ reached 6 , dried at $50^{\circ} \mathrm{C}$, and finally homogenized. These samples were analyzed for total organic carbon (TOC) and nitrogen (TON) at the Stable Isotope Laboratory of the Center for Nuclear Energy in Agriculture (CENA/USP). The results were expressed as a percentage of dry weight, with analytical precision of $0.09 \%$ (TOC) and $0.07 \%$ (TON), respectively.

\section{Radiocarbon Dating}

Based on color, lithology, and/or texture discontinuities, 7 bulk samples (10 g each) were selected for ${ }^{14} \mathrm{C}$ analysis. To avoid natural contamination by shell fragments, roots, seeds, etc. (e.g. Goh 1978), the sediment samples were physically cleaned under the stereomicroscope. Organic matter was extracted from the sediments according to the laboratory standard pre-treatment with an acid-alkali-acid wash (Pessenda et al. 2012).

A chronologic framework for the sedimentary sequence was provided by accelerator mass spectrometer (AMS) dating at Fluminense Federal University (LACUFF) and the University of Georgia Center for Applied Isotope Studies (UGAMS). ${ }^{14} \mathrm{C}$ ages were normalized to a $\delta^{13} \mathrm{C}$ value of $-25 \%$ VPDB and reported as calibrated years (cal yr BP) (2 $\sigma)$ using CALIB 6.0 and the SHCal13 curve (Reimer et al. 2009). The dates are reported in the text as the median of the range of calibrated ages (Table 1). The sedimentation rates were based on the ratio between the depth intervals $(\mathrm{mm})$ and the time range.

\section{RESULTS}

\section{Fluvial Geomorphology}

The study area lies along the Jucuruçu River valley (Figure 1), with the core site (PR07) 23 km inland from the current coast. The topographic difference between the river floodplain and 
Table 1 Sediment samples selected for ${ }^{14} \mathrm{C}$ dating with code site, laboratory number, depth, material, ${ }^{14} \mathrm{C}$ yr BP and calibrated (cal) ages and median of cal ages.

\begin{tabular}{llcll}
\hline Sample & Laboratory code & ${ }^{14} \mathrm{C}$ yr BP & ${ }^{14} \mathrm{C}$ cal yr BP $(2 \sigma)$ & Mean \\
\hline PR 07 52-54 & UGAMS 20331 & $2380 \pm 20$ & $2314-2436$ & 2400 \\
PR 07 106-109 & UGAMS 20332 & $3550 \pm 20$ & $3822-3900$ & 3861 \\
PR 07 170-172 & UGAMS 20333 & $4760 \pm 20$ & $5325-5411$ & 5350 \\
PR 07 211-214 & UGAMS 20334 & $5550 \pm 25$ & $6274-6355$ & 6300 \\
PR 07 392-394 & LACUF 140149 & $6488 \pm 100$ & $7168-7517$ & 7350 \\
PR 07 446-449 & LACUF 140004 & $6536 \pm 38$ & $7311-7487$ & 7400 \\
PR 11 65 & UGAMS 21205 & $690 \pm 20$ & $648-678$ & 660 \\
\hline
\end{tabular}

adjacent plateau is $\sim 70 \mathrm{~m}$ (Figure 1b). A striking characteristic of the Jucuruçu River is its modern channel pattern, which is mostly straight to only slightly sinuous along its southeastern stretch, in contrast with the meandering pattern along its northwestern stretch and in its mouth (Figure 1a). It flows over the Barreiras Formation into the coastal plain through a valley floodplain with an elevation near the study site between 3.5 and $7 \mathrm{~m}$ above the RSL (Figures 1a,b). The fluvial deposits are predominantly comprised of moderately sorted, medium to very coarse-grained sands. The floodplains and tidal flats are characterized by peat and muddy silt sediments. Abandoned meander channels occur throughout the floodplain (Figure 1a). Avulsion may have been responsible for the partial or complete abandonment of several channels due to rapid sand accumulation (Figure 1a).

\section{Vegetation}

The plateaus (1000 $\mathrm{km}^{2}$, Figure 1a) are covered with a mixture of Atlantic Forest $\left(\sim 100 \mathrm{~km}^{2}\right)$, plantation/pasture $\left(\sim 420 \mathrm{~km}^{2}\right)$ and bare ground $\left(\sim 116 \mathrm{~km}^{2}\right)$ (Figure $\left.1 \mathrm{~b}\right)$, while the floodplains are dominated by herbaceous vegetation $\left(\sim 130 \mathrm{~km}^{2}\right)$ (Cyperaceae and Poaceae) (Figure 1a). Gallery vegetation grows along the scarps, mainly comprising Arecaceae, covering $\sim 170 \mathrm{~km}^{2}$. Downstream, sandy silt and muddy sediments spread over the floodplain, which is partially covered by várzea vegetation (seasonal swamp lands), while the tidal plain is generally colonized by mangroves (Figure 1a). The limit between freshwater and mangrove vegetation is not always clearly fixed because the transition between these vegetation units reflects a salinity gradient, whereby the vegetation mainly characterized by Arecaceae (freshwater vegetation) occurs upstream, while mangroves occupy zones under marine influence (Figure 1a). Mangroves, which cover $\sim 8 \mathrm{~km}^{2}$ close to marine influence, occur as a fringe along tidal channels in the study area, but between the study site and Espírito Santo littoral zone, mangroves develop along the barrier and coastal lagoon system. They are characterized by Rhizophora, Laguncularia and Avicennia, occupying areas between 0.3 and $1.0 \mathrm{~m}$ above the mean sea level. Coastal sand barriers occur parallel to the shore and are sometimes separated from the mainland by lagoons. This geomorphological unit is colonized by restinga vegetation, which is mainly dominated by palm trees, as well as Ipomoea pes-caprae, Hancornia speciosa, Chrysobalanus icaco, Hirtella americana, Cereus fernambucensis and Anacardium occidentale. In our study area restinga covers about $16 \mathrm{~km}^{2}$.

\section{Radiocarbon Dates and Sedimentation Rates}

The ${ }^{14} \mathrm{C}$ dates are shown in Table 1 , and no age inversions were observed. The calculated sedimentation rates are $11 \mathrm{~mm} / \mathrm{yr}(449-394 \mathrm{~cm}), 1.7 \mathrm{~mm} / \mathrm{yr}(394-214 \mathrm{~cm}), 0.5 \mathrm{~mm} / \mathrm{yr}(214-172 \mathrm{~cm})$, 


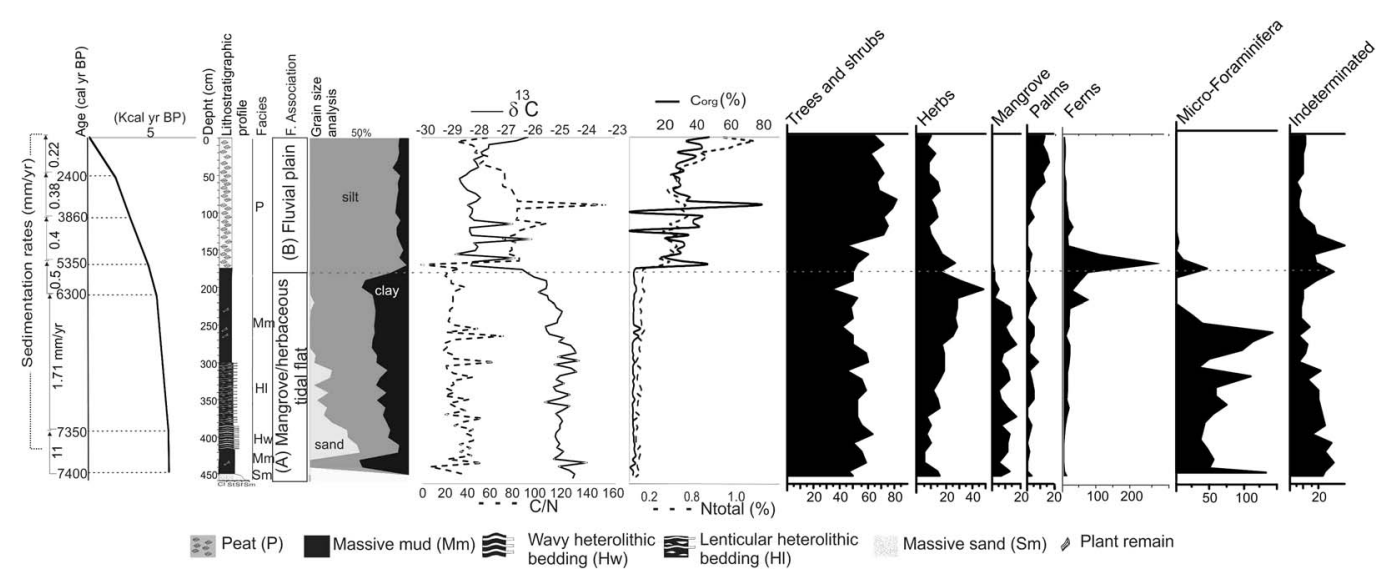

Figure 3 Summarized results for core PR07 with variation as a function of core depth showing chronological and lithological profiles with sedimentary facies, as well as ecological pollen groups and geochemical variables. Pollen data are presented in the pollen diagrams as percentages of the total pollen sum.

$0.4 \mathrm{~mm} / \mathrm{yr}(172-109 \mathrm{~cm}), 0.38 \mathrm{~mm} / \mathrm{yr}(109-54 \mathrm{~cm})$, and $0.22 \mathrm{~mm} / \mathrm{yr}(54-0 \mathrm{~cm})$. Although the rates are nonlinear between the dated layers, they fall within the same order of magnitude as the vertical accretion range of 0.1 to $11 \mathrm{~mm} \mathrm{yr}^{-1}$ for mangrove forests reported by other authors (Behling et al. 2001; Cohen et al. 2009).

\section{Facies, Pollen Description, and Isotope Values from Sediment Core}

The textural analysis and sedimentary structures associated with the pollen records, combined with $\delta^{13} \mathrm{C}$, and $\mathrm{C} / \mathrm{N}$ values, allow the identification of two facies associations related to a typical tidal and fluvial channel (Figures 3 and 5). These include mangrove/herbaceous tidal flat and fluvial plain.

\section{Facies Association A (Mangrove Herbaceous Tidal Flat)}

Nowadays, the spatial association between mangrove and herbaceous vegetation may be observed near the mouth of the Jucuruçu River (Figure 1a). As previously described in the "Vegetation" section, the salinity gradient resulted in a mixed vegetation community, with Rhizophora (mangrove) trees, which occur under lower salinity than Avicennia trees, and Cyperaceae and Poaceae (herbaceous plain), as well as some Arecaceae (várzea) trees on the fluvial/tidal floodplain.

This facies association corresponds to the sedimentary unit between 4.6 and $1.75 \mathrm{~m}$ depth in the sediment core PR07, dated to 7400 and 5350 cal yr BP. Along the PR11 this facies association occurs between 148 and $0 \mathrm{~cm}$ depth with a date of $660 \mathrm{cal}$ yr BP at $65 \mathrm{~cm}$ depth. These deposits consist of massive muds (facies $\mathrm{Mm}$ ), massive sands (Sm), and lenticular ( $\mathrm{Hl})$ and wavy heterolithic bedding (facies $\mathrm{Hw}$ ). Bioturbation structures are locally present, caused by roots and leaves deposited between the sediment layers (Figure 3).

The pollen assemblage in core PR07 is characterized by four ecological groups (Figures 4 and 5), defined by the presence of tree and shrubs (40-65\%) represented by Myrtaceae $(0-10 \%)$, Ilex (1-4\%), Fabaceae (9-20\%), Smilacaceae (0-10\%), Moraceae/Urticaceae (0-15\%), Rubiaceae (0-10\%), Anacardiaceae (0-5\%), Apocynaceae (1-5\%), Euphorbiaceae (1-15\%), Alchornea 


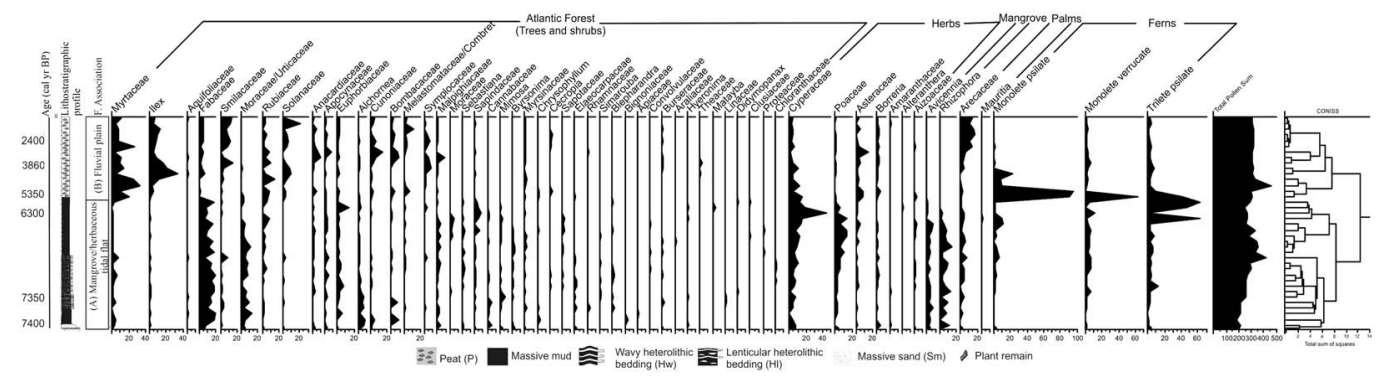

Figure 4 Pollen diagram of core PR07 with percentages of the most frequent pollen taxa, sample ages, and cluster analyses.

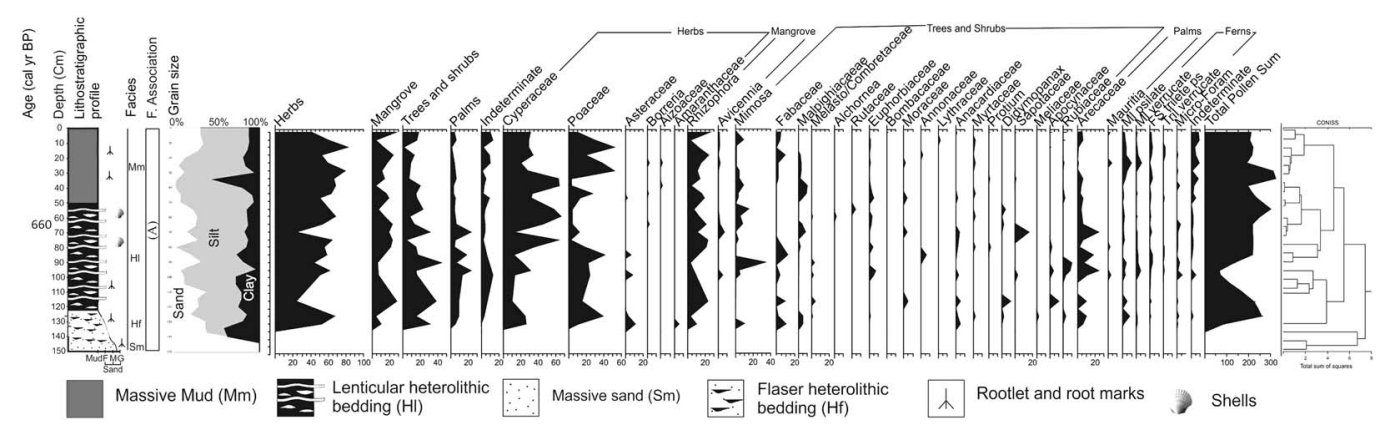

Figure 5 Pollen diagram of PR11 with lithological profiles, sedimentary facies, ecological pollen groups and percentages of the most frequent pollen taxa.

$(2-10 \%)$, Bombacaceae $(0-10 \%)$ and Malpighiaceae (1-5\%). Herbaceous pollen percentages rise progressively from 5 to $50 \%$, predominantly Cyperaceae (2-45\%), Poaceae (0-14\%), Asteraceae $(0-5 \%)$ and Borreria $(0-5 \%)$. Pollen of mangrove taxa also occur within this facies association, namely Rhizophora (1-15\%) and Avicennia (3-7\%). Arecaceae occurs between 0-9\%.

Similarly, pollen analysis for core PR11 also revealed four ecological groups (Figure 5), defined by the presence of trees and shrubs $(5-45 \%)$ that presents a decrease trend from the bottom $(40 \%)$ to the top (15\%) mainly represented by Melastomataceae/Combretaceae (0-5\%), Mimosa $(0-35 \%)$, Malpighiaceae (0-10\%), Euphorbiaceae (0-10\%), Fabaceae (0-11\%), Moraceae/Urticaceae (0-5\%), Rubiaceae (0-10\%), and Alchornea (0-1\%). Herbaceous pollen percentage oscillated between 25 and $80 \%$, predominantly represented by Cyperaceae (10-65\%), Poaceae (5-50\%), Asteraceae $(0-12 \%)$, and Borreria (0-3\%). Pollen of mangrove taxa (5-28\%) also occur within this facies association, represented by Rhizophora (5-25\%) and Avicennia (0-9\%). Arecaceae occurs between 0 and 25\%.

The sedimentary organic carbon in core PR07 presents percentages between $0.6 \%$ and $6.5 \%$, while total nitrogen exhibits values between $0.06 \%$ and $0.14 \%$. The $\delta^{13} \mathrm{C}$ and $\mathrm{C} / \mathrm{N}$ values oscillate between -24 and $-26 \%$ o (mean $=-25 \%$ ), and 7.3 and $67($ mean $=25)$, respectively (Figure 3$)$.

\section{Facies Association B (Fluvial Plain)}

Facies Association B, identified only in PR07, characterizes the sediment unit between $1.8 \mathrm{~m}$ depth and the core top and was deposited during the last $5350 \mathrm{cal} \mathrm{yr}$ BP. This deposit consists of 
a massive organic dark gray mud (facies MOM) with roots, root marks, and leaves (Figure 3). Along this interval organic matter prevails with little mud.

The palynological record in these facies is marked by the absence of mangrove pollen. Pollen of trees and shrubs dominate and show a slight increase from 65 to $83 \%$. Key tree/shrub taxa are Myrtaceae (4-34\%), Ilex (1-34\%), Fabaceae (0-19\%), Smilacaceae (2-15\%), Moraceae/Urticaceae (0-4\%), Rubiaceae (2-16\%), Solanaceae (2-23\%), Cunoniaceae (1-19\%), Melastomataceae/ Combretaceae (1-13\%), Anacardiaceae (1-11\%), Apocynaceae (1-9\%), Bombacaceae (0-9\%), Symplocaceae (0-9\%), Euphorbiaceae (1-4\%), Alchornea (0-3\%), and Malpighiaceae (1-9\%). Herb pollen percentages decline from 27 to $7 \%$, and are mainly characterized by Cyperaceae (3-16\%), Asteraceae (1-16\%), Borreria $(1-6 \%)$ and Poaceae $(0-3 \%)$. Arecaceae increases from 3 to $18 \%$.

Along this facies association the sedimentary organic carbon presents a significant increase from 4 to $47 \%$, with oscillation between 21 and $78 \%$. The total nitrogen exhibits similar trend increasing from 0.3 to $1.15 \%$. The $\delta^{13} \mathrm{C}$ and $\mathrm{C} / \mathrm{N}$ values oscillate between -26 and $-28 \%$ o $($ mean $=-27 \%$ ), and between 22 and $159($ mean $=90)$, respectively (Figure 3$)$.

\section{INTERPRETATION AND DISCUSSION}

\section{Middle Holocene: Mangrove/Herbaceous Tidal Flat}

It is likely that the fining-upward facies succession and mud accumulation during this phase signifies the abandonment of the tidal channel. This stratigraphic interpretation is based, not only on changes in sediment grain size and structures, but also the modern geomorphological features of the study site, such as the numerous abandoned channels along the river valley (Figure 1a). The latter were caused by channel-shifting processes, such as meander cutoff and channel-belt avulsion (Toonen et al. 2012). Muddy sediments under tidal influence filled the depressions of abandoned channels until the development of a tidal flat with its typical wavy and lenticular heterolithic bedding. The intertidal flats are generally bordered by estuarine/tidal channels in a sheltered coastal environmental. The stabilization of RSL, and its subsequent fall, built up an upward-fining succession, with thick sand deposition succession at the base, including subtidal channel-filling facies, topped by intertidal muddy deposits. This intertidal flat comprises sediments with well-developed wavy bedding at the base, and lenticular bedding at the top, overlapped by wetland deposits. Palynological evidence for the presence of mangrove vegetation, together with micro-foraminifera (Kumaran et al. 2004), indicate an estuarine influence between 7400 and 5350 cal yr BP.

The $\delta{ }^{13} \mathrm{C}$ and $\mathrm{C} / \mathrm{N}$ data provide further corroborating evidence that estuarine organic matter accumulated during the mangrove phase (Figure 6). Mangroves, herbs, and palms occupied the tidal flat in the margin of the estuarine/tidal channel, while the trees and shrubs occupied the plateau. The relatively low mangrove pollen percentages (5-20\%), which may indicate small or non-local mangrove areas in the study site, may be caused by the elevated pollen inflow of trees and shrubs (Atlantic Forest) from the plateau, since this vegetation, outside of the valley, is not influenced by sea-level changes.

\section{Late Holocene: Fluvial Plain}

The peat deposit with accumulation of partially decayed vegetation and organic matter with mud presents an increased trend of trees, shrubs, and palms pollen (Figure 3). This phase is characterized by the disappearance of mangroves in sampling site PR07 and their migration 


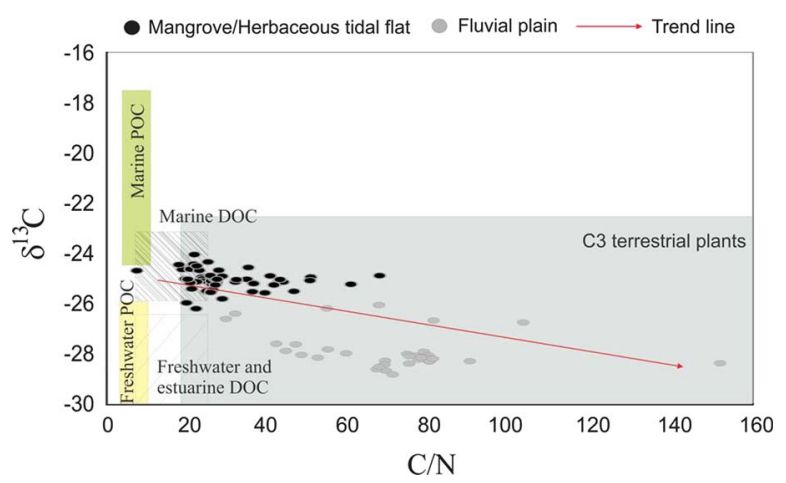

Figure 6 Diagram illustrating the relationship between $\delta^{13} \mathrm{C}$ and $\mathrm{C} / \mathrm{N}$ for the different sedimentary facies (mangrove/herbaceous tidal flat and fluvial plain) with interpretation according to data presented by Lamb et al. (2006), Meyers (2003), and Wilson et al. (2005).

seaward, with an increased influence of $\mathrm{C}_{3}$ terrestrial plants over a fluvial plain during the late Holocene (Figures 3 and 6) and establishment of mangroves on the modern coast, where core PR11 was sampled (Figure 5). Nowadays, mangrove trees are positioned $\sim 34 \mathrm{~km}$ away from the sampling site PR07 at the mouth of the Jucuruçu River, where core PR11 was sampled. According to core PR11, this mangrove forest occurred at the mouth of this river at least during the last $660 \mathrm{cal} \mathrm{yr}$ BP. This distance and topographic position prevent the wind transport of mangrove pollen grain to sampling site PR07.

The pollen content of core PR11 reflects a mangrove forest and other vegetation units that are spatially $(34 \mathrm{~km})$, topographically $(-2.7 \mathrm{~m})$, and temporally $(4700 \mathrm{yr})$ distant from the mangrove phase of PR07. However, the data of PR11 reveal a pollen assembly like that of PR07 during the mangrove phase. Some differences can be identified in taxa as representative of trees and shrubs. Probably, these are caused by the distance of the PR 11 site relative to the plateau that is colonized by the Atlantic Forest, the main source of trees and shrubs pollen grains to core PR07. In addition, probably the interaction between the most distal portion of the humid evergreen Atlantic Forest and the Restinga vegetation, near the coastline, is influencing the trees and shrubs pollen group along PR11.

Then, as evidenced by evaluation of these two pollen profiles, it is reasonable to assume that pollen assembly, preserved along the sediment deposits of tidal flats of core PR07, reflects the vegetation units of the study area during the middle and late Holocene.

Regarding the transition from facies Association A to B in PR07, it is marked also by the expansion of ferns that indicate a decrease in water salinity. The disruption of the mangrove ecosystem during this period indicates unfavorable conditions for mangrove development, which may have been due to decreased pore-water salinity. This salinity decrease would have allowed the colonization of the study site by herbs, shrubs, palms, and ferns (Figure 6). This last phase of environmental change is a consequence of the combined action of RSL fall and increase in fluvial discharge, the latter driven by increasing rainfall in the river catchment.

\section{Holocene Sea-Level Changes and Mangroves}

Mangroves are useful indicators of coastal dynamics because their position within the intertidal zone is strongly influenced by sea-level changes (Woodroffe 1995; Cohen et al. 2012). Over a 
range of sea-level rise scenarios, coastal wetlands adjust toward an equilibrium with sea level (D'Alpaos et al. 2008). Equilibrium models predict that coastal wetlands have a number of feedbacks that allow them to maintain their position relative to the mean tide (Furukawa and Wolanski 1996; Cohen et al. 2005; Cahoon et al. 2006).

Therefore, paleoenvironmental analyses of sediments deposited beneath mangrove vegetation can provide a record of former sea-level change (Cohen et al. 2005; Woodroffe 1981). Regarding the northern Brazilian littoral zone, macrotidal mangroves occur between 1 and $2.4 \mathrm{~m}$ above the mean sea level (Cohen et al. 2005b), while the mangroves on the study site are spread between 0.3 and $1 \mathrm{~m}$ above the mean sea level. Then, in the study site, we have used as reference to the relative sea level (RSL) the mean topographic distribution of the modern mangroves $(0.65 \pm 0.35 \mathrm{~m}$ above the mean sea level).

The data from the study site suggest that mangrove vegetation and estuarine organic matter developed on a tidal plain along a fluvial valley between $\sim 7400$ and $5350 \mathrm{cal}$ yr BP. This phase was followed by a decrease in mangrove habitat and an expansion of C3 terrestrial plants (Figure 6), probably represented by herbs and palms (Figure 3), like the modern vegetation along the Jucuruçu fluvial valley (Figure 1c). These results indicate a local impact of that RSL fall during the late Holocene, causing a forced regression of the northeastern Brazilian shoreline, that in turn drove delta progradations (Cohen et al. 2014). Subsequently, along the fluvial valleys, a pattern of facies succession can be observed, whereby estuarine sediments give way to a more fluvially dominated stratigraphy as marine and tidal influence decreases (Figures 3 and 6$)$. In addition, the relatively low organic carbon percentage $(\sim 5 \%)$ during the development of mangrove/herbaceous tidal flat ( 7400 and 5350 cal yr BP) and the high organic carbon percentage $(>10 \%)$ during the fluvial plain development $(<5350 \mathrm{cal} \mathrm{yr} \mathrm{BP})$ may be attributed to the RSL changes (Figure 3), since during a RSL rise more space is created to accommodate new sediments, causing an increase in sedimentation rates. Conversely, during a RSL fall occurs a decrease in sedimentation or erosion. Then, in the studied site, a relative sea level fall may have caused a decrease in sedimentary particles accumulation and consequently an increase in the proportion of organic matter supplied by freshwater herbaceous plain.

Regarding the RSL curves for the Bahia littoral, Suguio et al. (1985) proposed a RSL crossing times at $7100 \mathrm{yr}$ BP in Salvador-Bahia. However, the MSL-crossing time in Salvador was based on a single sample: a reworked shell embedded in a beach-rock indicating an elevation of $0 \pm 0.5 \mathrm{~m}$ at $7792-7334 \mathrm{cal}$ yr BP (Martin et al.1979a). This altitude interpretation was based on primary sedimentary structures observed in the beach-rock. The authors inferred the age of the deposit by the age of transported samples, which can be much older than the deposit itself (Angulo et al. 2006). Besides, Lessa and Angulo (1998) suggested that the depositional environment should be at least $1.5 \mathrm{~m}$ higher. Considering the mid-Holocene highstand in the region around Salvador, at about 5783-5291 cal yr BP, the sea-level was $4.7 \pm 0.5 \mathrm{~m}$ (Martin et al. 1979a, 2003) or $4.5 \pm 0.5 \mathrm{~m}$ (Martin et al.1979b) or $4.8 \pm 0.5 \mathrm{~m}$ (Suguio et al.1985).

Regarding the present work and the topographic level of the sampling site PR07, about $4.5 \pm 1 \mathrm{~m}$ above the RSL, the lower part of the facies association mangrove/herbaceous tidal flat (A), at $4.5 \mathrm{~m}$ depth ( 7400 cal yr BP) $(0.05 \pm 1 \mathrm{~m}$ below the RSL), signifies a marine influence along the fluvial valley $34 \mathrm{~km}$ upstream from its current mouth. Taking into account the modern mangrove distribution zone between 0.3 and $1 \mathrm{~m}( \pm 0.35)$ above the mean sea-level in the study area, and the margin of error of the SRTM topographic data of $\sim 1 \mathrm{~m}$, we infer 


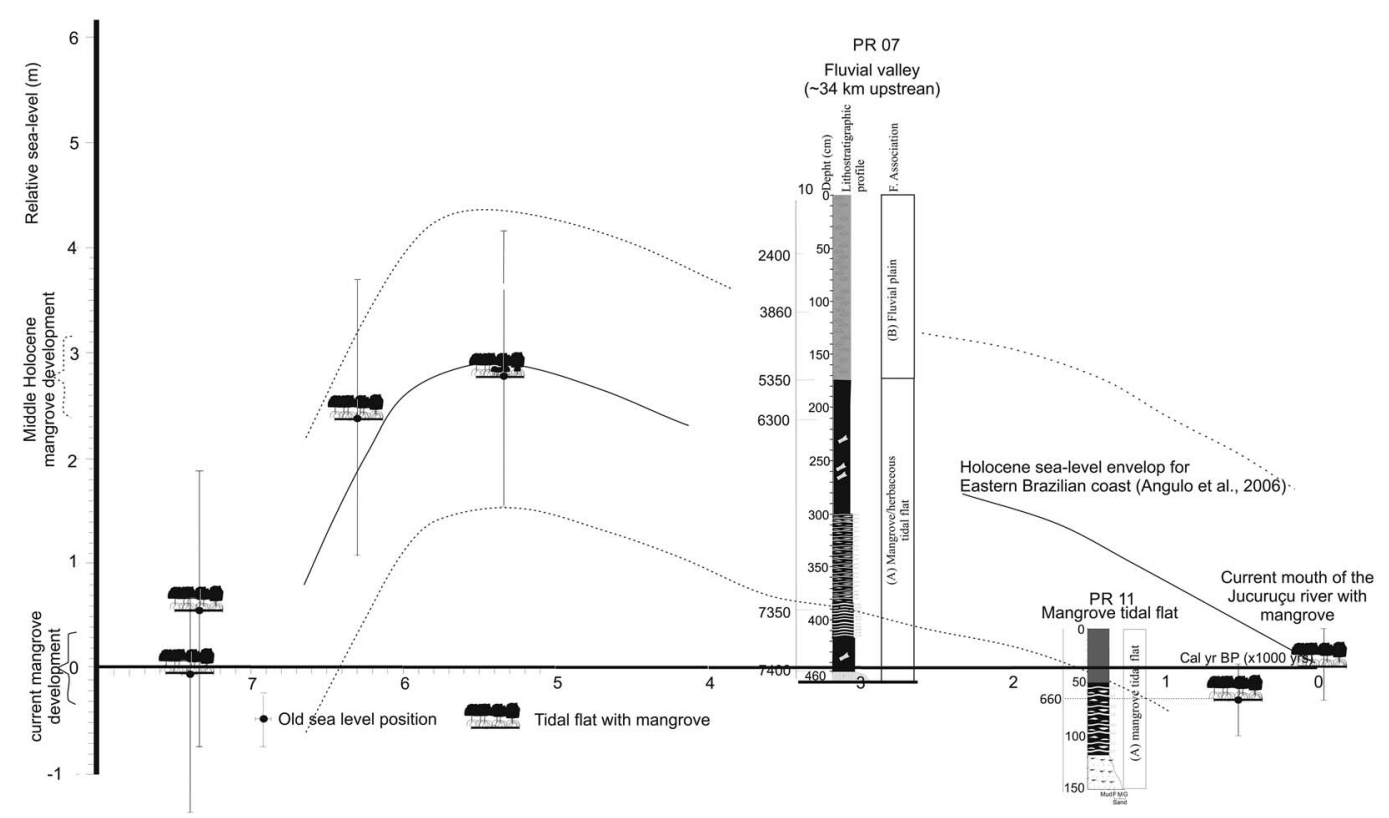

Figure 7 Sea-level envelope for the eastern Brazilian coast based on vermetid samples (Angulo et al. 2006) and Holocene paleo-sea-level reconstructions for the southern Bahia littoral based on mangrove sediments.

that the RSL at about 7400 cal yr BP along the littoral zone of Prado-BA was between $0 \pm 1.35$ and $0.55 \pm 1.35 \mathrm{~m}$ (Figure 7$)$. During the subsequent mangrove phase ( 7400 to $\sim 5350$ cal yr BP), sedimentation rates were substantially higher $(11-0.5 \mathrm{~mm} / \mathrm{yr})$ than in the succeeding herbaceous-plain phase $(0.4-0.22 \mathrm{~mm} / \mathrm{yr})$ deposited since $\sim 5350 \mathrm{cal} \mathrm{yr}$ BP (Figure 4). Probably, it is related to the rapid post-glacial sea-level rise that peaked in the mid-Holocene, when more space was created to accommodate new sediments. RSL subsequently fell during the late Holocene with decrease or absence in sediment accommodation space.

The upper part of the Facies Association A, which occurs at $175 \mathrm{~cm}$ depth $(2.75 \mathrm{~m}$ above the RSL), suggests a maximum RSL during the mid-Holocene of about $2.75 \pm 1.35$ (Figure 7).

Along the coast of southeastern Brazil, higher RSL during the middle Holocene led to the formation of numerous lagoons, estuaries and mangrove-dominated tidal flats (Cohen et al. 2014). This marine incursion along the studied fluvial valley led to mangrove expansion and deposition of estuarine organic matter upriver. Over the last $5350 \mathrm{cal}$ yr BP there was a subsequent retraction and local disappearance of mangroves, which were replaced by herbaceous $\mathrm{C} 3$ vegetation forming an open fluvial plain.

Core PR 11 was sampled from a modern mangrove area and according to the hydrotopographic devices, it is positioned $0.35 \mathrm{~m}$ above the RSL. In this case, only the vertical error of $\pm 0.35 \mathrm{~m}$, associated to the topographic distribution of modern mangroves in the study site, was considered. Then, considering the dated sedimentary organic matter at $65 \mathrm{~cm}$ depth $(0.3 \mathrm{~m}$ below the RSL $)$ and accumulated under mangrove vegetation, likely the RSL at about $660 \mathrm{cal}$ yr BP was $-0.3 \pm 0.35 \mathrm{~m}$. Therefore, between 5350 and $660 \mathrm{cal}$ yr BP the mangrove vegetation along the Jucuruçu River migrated $34 \mathrm{~km}$ downstream in a topographic gradient of $2.7 \pm 1.35 \mathrm{~m}$. 


\section{Holocene Climatic Changes}

Given that one of the key components controlling the coastal depositional systems is the sea-level changes, then, generally only this important driving force is considered in the interpretation of the coastal stratigraphic sequences (e.g. Tanoli 2014; Fruergaard et al. 2015; Woodroffe et al. 2015). However, areas where there are strong fluvial discharges, such as the northern Brazilian coast, near the Amazon River, the climate component may even prevail on the RSL component, when analyzing indicator elements (e.g. sedimentary features, pollen, sedimentary organic matter) of palaeovegetation and palaeoenvironment that composes a stratigraphic sequence (Cohen et al. 2012). Then, a combined effect of the RSL plus climate change on coastal environments is expected mainly near the fluvial discharges (França et al. 2013; Cohen et al. 2014). In this context, the relative importance of sea-level variation versus climate changes as drivers of vegetation and coastal system dynamics depends upon the specific geomorphological characteristics of the study site (Roe and van de Plassche 2005; Woodroffe and Murray-Wallace 2012).

Regarding the study site, it is located in a fluvial valley (Figure 1), $23 \mathrm{~km}$ inland from the current coastline and with significant topographical relief of $\sim 70 \mathrm{~m}$ between the fluvial terrace and the adjacent plateau. Nowadays, this plateau ( $\sim 70 \mathrm{~m}$ above the flood plain) is colonized by humid evergreen Atlantic Forest and, obviously, it has never been influenced by Holocene sea-level changes. Our core site PR07 receives pollen input, not only from the valley floodplain, but also the adjacent forest-covered plateau. The fossil pollen record in the sediment core PR07 (Figures 4 and 5) therefore reveals changes in estuarine versus fluvial/floodplain ecosystems in relation to changes in RSL, and changes in the plateau vegetation, potentially driven by climate change.

In this context, we interpret the transition from estuarine to fluvial influence, at about 5350 cal yr BP, to be predominantly due to a fall in RSL, but also due to a trend of increasing precipitation, which likely increased the sediment and freshwater supply to the coastal system and contributed to the retraction of mangroves from the river valley study site to the coast (Figure 1a). In addition, the decrease of herbaceous pollen percentage and increase of trees and shrubs during the middle and late Holocene may be attributed to an increase of rainfall rates (Figure 3) influencing the vegetation on plateau. A previous study (Prado et al. 2013) suggested an early to mid-Holocene water deficit scenario in eastern South America compared to the late Holocene. Paleoenvironmental studies in Brazil indicate relatively drier climatic conditions during the early Holocene in central (Barberi et al. 2000), southeastern (Ledru et al. 1996; Pessenda et al. 2009) and southern regions of Brazil (Neves and Lorscheitter 1995; Pessenda et al. 2004). The middle to late Holocene climate was marked by wetter conditions (Pessenda et al. 2004, 2009). During this period, higher rainfall generated increased river discharge and more intensified continental conditions.

Therefore, changes in rainfall regime caused changes in fluvial discharge and estuarine salinity gradients (Lara and Cohen 2006), which, in tandem with the aforementioned salinity changes caused by changes in RSL, drove mangrove dynamics (Cohen et al. 2012). With respect to our specific study area, we therefore infer that the climate-driven increase in river discharge caused a progressive reduction in water salinity, which caused the local replacement of mangroves by freshwater floodplain vegetation. Mangroves receded along the fluvial valley to occupy their current position on tidal flats and the edges of coastal lagoons (Figure 1a). The concomitant decline in RSL in the region would have exacerbated these climate-driven salinity changes and enhanced the mid-late Holocene coastal retreat of mangroves. 


\section{CONCLUSION}

This study indicates the presence of an estuarine system with tidal flats colonized by mangroves at least $34 \mathrm{~km}$ upstream, and its sedimentary organic matter sourced from estuarine organic matter during the middle Holocene (between 7400 and $\sim 5350$ cal yr BP). During the mid-late Holocene (the past $5350 \mathrm{cal}$ yr BP), the mangroves shrank and herbaceous vegetation in the valley floodplain expanded (terrestrial $\mathrm{C}_{3}$ plants), likely caused by the combined effects of a reduction in RSL and increased freshwater supply. During the early-middle Holocene there was a rise in RSL with a highstand at about $5350 \mathrm{cal}$ yr BP of $2.7 \pm 1.35 \mathrm{~m}$, which caused a marine incursion along the fluvial valley. Drier climatic conditions during the early-middle Holocene would have decreased the fluvial discharge, thereby contributing to this marine transgression. However, during the mid-late Holocene RSL fell and precipitation increased, this combined effect caused the restriction of mangroves to the tidal flats attached to the edge of lagoons near the modern coastline.

\section{ACKNOWLEDGMENTS}

We would like to thank the Vale Nature Reserve (Linhares, ES). This study was financed by FAPESP (03615-5/2007 and 00995-7/11), CNPq (470210/2012-5 and 405060/2013-0), and by the National Institute on Science and Technology in Tropical Marine Environments INCT-AmbTropic (CNPq Process 565054/2010-4).

\section{REFERENCES}

Alongi DM. 2015. The impact of climate change on mangrove forests. Current Climate Change Reports 1:30-9.

Angulo R, Lessa G, Souza M. 2006. A critical review of mid- to late-Holocene sea-level fluctuations on the eastern Brazilian coastline. Quaternary Science Reviews 25:486-506.

Barberi M, Salgado-Labouriau ML, Suguio K. 2000. Paleovegetation and paleoclimate of "Vereda de Águas Emendadas", central Brazil. Journal of South American Earth Sciences 13:241-54.

Behling H, Cohen MCL, Lara RJ. 2001. Studies on Holocene mangrove ecosystem dynamics of the Bragança Peninsula in north-eastern Pará, Brazil. Palaeogeography, Palaeoclimatology, Palaeoecology 167:225-42.

Blasco F, Saenger P, Janodet E. 1996. Mangroves as indicators of coastal change. CATENA 27:167-78.

Boski T, Bezerra FHR, de Fátima Pereira L, Souza AM, Maia RP, Lima-Filho FP. 2015. Sea-level rise since $8.2 \mathrm{ka}$ recorded in the sediments of the Potengi-Jundiai Estuary, NE Brasil. Marine Geology 365:1-13.

Cahoon DR, Hensel PF, Spencer T, Reed DJ, McKee KL, Saintilan N. 2006. Coastal wetland vulnerability to relative sea-level rise:wetland elevation trends and process controls. In: Verhoeven JTA, Beltman B, Bobbing R, Whigham DF, editors. Wetlands and Natural Resource Management. Berlin: Springer-Verlag. p 271-92.

Caldas LHO, Oliveira JJG, Medeiros WE, Stattegger K, Vital H. 2006. Geometry and evolution of Holocene transgressive and regressive barriers

on the semi-arid coast of NE Brazil. Geo-Marine Letters 26(5):249-63.

Castro JWA, Suguio K, Seoane JCS, Cunha AM, Dias FF, Castro JWA, Suguio K, Seoane JCS, Cunha AM, Dias FF.. 2014. Sea-level fluctuations and coastal evolution in the state of Rio de Janeiro, southeastern Brazil. Anais da Academia Brasileira de Ciências 86:671-83.

Church JA, Clark PU, Cazenave A, Gregory JM, Jevrejeva S, Levermann A, Merrifield MA, Milne GA, Nerem RS, Nunn PD, Payne AJ, Pfeffer WT, Stammer D, Unnikrishnam AS. 2013. Sea level change. In: Stocker TF, Qin D, Plattner G-K, Tignor M, Allen SK, Boschung J, Nauels A, Xia Y, Bex V, Midgley PM, editors. Climate Change 2013: The Physical Basis, Contribution of Working Group I to the Fifth Assessment Report of the Intergovernmental Panel on Climate Change. Cambridge. p 1029-136.

Cohen MCL, Lara J. 2003. Temporal changes of mangrove vegetation boundaries in Amazonia: application of GIS and remote sensing techniques. Wetlands Ecology and Management 11:223-31.

Cohen MCL, Souza Filho PWM, Lara RJ, Behling H, Angulo RJ. 2005. A model of holocene mangrove development and relative sea-level changes on the Bragança Peninsula (Northern Brazil). Wetlands Ecology and Management 13:433-43.

Cohen MCL, Behling H, Lara RJ, Smith CB, Matos HRS, Vedel V. 2009. Impact of sea-level and climatic changes on the Amazon coastal wetlands during the late Holocene. Vegetation History and Archaeobotany 18:425-39. 
Cohen MCL, Pessenda LCR, Behling H, de Fátima Rossetti D, França MC, Guimarães JTF, Friaes Y, Smith CB. 2012. Holocene palaeoenvironmental history of the Amazonian mangrove belt. Quaternary Science Reviews 55:50-8.

Cohen MCL, França MC, Rossetti DF, Pessenda LCR, Giannini PCF, Lorente FL, Buso A Jr, Castro D, Macario K. 2014. Landscape evolution during the late Quaternary at the Doce River mouth, Espírito Santo State, southeastern Brazil. Palaeogeography, Palaeoclimatology, Palaeoecology 415:48-58.

D’Alpaos A, Lanzoni S, Marani M, Rinaldo A. 2008. Landscape evolution in tidal embayments: modelling the interplay of erosion, sedimentation, and vegetation dynamics. Journal of Geophysical Research 112:1-17.

DHN. 2014. Directorate of Hydrography and Navigation. Tide table. Porto De Ilhéus - Malhado - BA.

Erdtman G. 1960. The acetolysis method. Svensk Botanisk Tidsskrift 54:561-4.

França MC, Cohen MCL, Pessenda LCR, Rossetti DF, Lorente FL, Buso AÁ Jr, Guimarães JTF, Friaes Y, Macario K. 2013. Mangrove vegetation changes on Holocene terraces of the Doce River, southeastern Brazil. CATENA 110:59-69.

França MC, Alves ICC, Castro DF, Cohen MCL, Rossetti DF, Pessenda LCR, Lorente FL, Fontes NA, Buso AÁB Jr, Giannini PCF, Francisquini MI. 2015. A multi-proxy evidence for the transition from estuarine mangroves to deltaic freshwater marshes, southeastern Brazil, due to climatic and sea-level changes during the late Holocene. CATENA 128:155-66.

Fruergaard M, Andersen TJ, Nielsen LH, Johannessen PN, Aagaard T, Pejrup M. 2015. High-resolution reconstruction of a coastal barrier system: impact of Holocene sea-level change. Sedimentology 62:928-69.

Furukawa K, Wolanski E. 1996. Sedimentation in mangrove forests. Mangroves and Salt Marshes 1:3-10.

Goh KM. 1978. Removal of contaminants to improve the reliability of radiocarbon dates of peats. Journal of Soil Science 29:340-9.

Grimm EC. 1987. CONISS: a FORTRAN 77 program for stratigraphically constrained cluster analysis by the method of incremental sum of squares. Computers and Geosciences 13:13-35.

Krauss KW, Lovelock CE, McKee KL, López-Hoffman L, Ewe SML, Sousa WP. 2008. Environmental drivers in mangrove establishment and early development: a review. Aquatic Botany 89:105-27.

Kumaran KPN, Shindikar M, Limaye RB. 2004. Mangrove associated lignite beds of Malvan, Konkan: evidence for higher sea-level during the Late Tertiary (Neogene) along the west coast of India. Current Science 86:335-40.

Lara RJ, Cohen MCL. 2006. Sediment porewater salinity, inundation frequency and mangrove vegetation height in Bragança, North Brazil: an ecohydrology-based empirical model. Wetlands Ecology and Management 14:349-58.

Ledru M-P, Braga PIS, Soubiès F, Fournier M, Martin L, Suguio K, Turcq B. 1996. The last 50,000 years in the Neotropics (southern Brazil): evolution of vegetation and climate. Palaeogeography, Palaeoclimatology, Palaeoecology 123:239-57.

Lessa GC, Angulo RJ. 1998. Oscillations or not oscillations, that is the question-reply. Marine Geology 150:189-96.

Liang S, Zhou R, Dong S, Shi S. 2008. Adaptation to salinity in mangroves: implication on the evolution of salt-tolerance. Science Bulletin 53: 1708-15.

Lima JAS, Chagas CS, Manzatto CV, Assis DS, Perez DV, Pereira NR, Cunha TJF, Tosto SG. 2002. Distribuição de espécies arbóreas em fragmentos de vegetação natural no município de Prado - extremo sul da Bahia. Rio de Janeiro.

Mantelli LR, de Fatima Rossetti D, Albuquerque PG, de Morrison Valeriano M. 2009. Applying SRTM digital elevation model to unravel Quaternary drainage in forested areas of Northeastern Amazonia. Computers \& Geosciences 35:2331-7.

Martin L, Flexor JM, Vilas-Boas GS, Bittencourt ACSP, Guimarães MMM. 1979a. Courbe de variation du niveau relatif de la mer au cours des 7000 derniéres années sur un secteur homogéne du littoral brésilien (nord de Salvador-Bahia). In: Suguio K, Fairchild TR, Martin L, Flexor JM, editors. Proceedings of the International Symposium on Coastal Evolution in the Quaternary. p 264-95.

Martin L, Vilas-Boas GS, Flexor JM. 1979b. Introdução ao estudo do Quaternário do litoral do Estado da Bahia-Trecho Salvador Ilhéus. Revista Brasileira de Geociências 9:309-20.

Martin L, Dominguez JML, Bittencourt ACSP. 2003. Fluctuating Holocene sea levels in eastern and southeastern brazil: evidence from multiple fossil and geometric indicators. Journal of Coastal Research 19:101-24.

Martorano LG, Coutinho SCDA. 2003. Aspectos climáticos da região do Prado - BA. Rio de Janeiro: Embrapa Solos. http://ainfo.cnptia.embrapa.br/digital/ bitstream/CNPS/11566/1/comtec13_2003_prado.

Miall AD. 1978. Facies types and vertical profile models in braided river deposits: a summary. In: Miall AD, editor. Fluvial Sedimentology. Calgary: Canadian Society of Petroleum Geologists. p 597-604.

Monacci NM, Meier-Grünhagen U, Finney BP, Behling H, Wooller MJ. 2009. Mangrove ecosystem changes during the Holocene at Spanish Lookout Cay, Belize. Palaeogeography, Palaeoclimatology, Palaeoecology 280:37-46.

Neves P, Lorscheitter M. 1995. Upper Quaternary palaeoenvironments in the northern coastal plain of Rio Grande do Sul, Brazil. Quaternary of South America and Antarctic Peninsula 9:39-67. 
Peixoto AL, Gentry A. 1990. Diversidade e composição florística da mata de tabuleiros na Reserva Florestal de Linhares (Espírito Santo, Brasil). Revista Brasileira de Botânica 13:19-25.

Pessenda LCR, Ribeiro ADS, Gouveia SEM, Aravena R, Boulet R, Bendassolli JA. 2004. Vegetation dynamics during the late Pleistocene in the Barreirinhas region, Maranhão State, northeastern Brazil, based on carbon isotopes in soil organic matter. Quaternary Research 62:183-93.

Pessenda LCR, De Oliveira PE, Mofatto M, de Medeiros VB, Francischetti Garcia RJ, Aravena R, Bendassoli JA, Zuniga Leite A, Saad AR, Lincoln Etchebehere M. 2009. The evolution of a tropical rainforest/grassland mosaic in southeastern Brazil since $28,000{ }^{14} \mathrm{C}$ yr BP based on carbon isotopes and pollen records. Quaternary Research 71:437-52.

Pessenda LCR, Vidotto E, De Oliveira PE, Buso AA, Cohen MCL, Rossetti D, de F, Ricardi-Branco F, Bendassolli JA. 2012. Late Quaternary vegetation and coastal environmental changes at Ilha do Cardoso mangrove, southeastern Brazil. Palaeogeography, Palaeoclimatology, Palaeoecology 363:57-68.

Prado LF, Wainer I, Chiessi CM, Ledru M-P, Turcq B. 2013. A mid-Holocene climate reconstruction for eastern South America. Climate of the Past 9:2117-33.

Reading HG. 1996. Sedimentary Environments: Processes, Facies and Stratigraphy, 3rd edition. Blackwell Science.

Record S, Charney ND, Zakaria RM, Ellison AM. 2013. Projecting global mangrove species and community distributions under climate change. Ecosphere 4:34.

Reimer PJ, Baillie MGL, Bard E, Bayliss A, Beck JW, Blackwell PG, Bronk Ramsey C, Buck CE, Burr GS, Edwards RL, Friedrich M, Grootes PM, Guilderson TP, Hajdas I, Heaton TJ, Hogg AG, Hughen KA, Kaiser KF, Kromer B, McCormac FG, Manning SW, Reimer RW, Richards DA, Southon JR, Talamo S, Turney CSM, van der Plicht J, Weyhenmeyer CE. 2009. IntCal09 and Marine09 radiocarbon age calibration curves, 050,000 years CAL BP. Radiocarbon 51(4):1111-50.

Roe HM, van de Plassche O. 2005. Modern pollen distribution in a Connecticut saltmarsh: implications for studies of sea-level change. Quaternary Science Reviews 24:2030-49.
Rossetti D, de F, Polizel SP, Cohen MCL, Pessenda LCR. 2015. Late Pleistocene-Holocene evolution of the Doce River delta, southeastern Brazil: implications for the understanding of waveinfluenced deltas. Marine Geology 367:171-90.

Rossetti DF, Valeriano MM, Thales M. 2007. An abandoned estuary within Marajó Island: implications for late Quaternary paleogeography of northern Brazil. Estuaries and Coasts 30:813-26.

Roubik DW, Moreno JE. 1991. Pollen and Spores of Barro Colorado Island. Missouri Botanical Garden.

Suguio K, Martin L, Bittencourt AC, Bittencourt ACSP, Dominguez JML, Flexor J-M, De Azevedo AEG. 1985. Fluctuacões do nivel do mar durante o Quaternario superior ao longo do litoral Brasileiro e sus implicacões na sedimentação costeira. Revista Brasileira de Geociências 15:273-86.

Suguio K, Barreto AMF, Oliveira PE, Bezerra FHR, Vilela MCSH. 2013. Indicators of Holocene sea level changes along the coast of the states of Pernambuco and Paraíba, Brazil. Geologia - Série Científica USP 13:141-52.

Tanoli SK. 2014. Sedimentological evidence for the Late Holocene sea level change at the Enjefa Beach exposures of Kuwait, NW Arabian Gulf. Arabian Journal of Geosciences 8:6063-74.

Toonen WHJ, Kleinhans MG, Cohen KM. 2012. Sedimentary architecture of abandoned channel fills. Earth Surface Processes and Landforms 37: 459-72.

Walker RG. 1992. Facies, facies models and modern stratigrahic concepts. In: Walker RG, James NP, editors. Facies Models - Response to Sea Level Change. Ontario: Geological Association of Canada. p 1-14.

Woodroffe C. 1981. Mangrove swamp stratigraphy and Holocene transgression, Grand Cayman Island, West Indies. Marine Geology 41:271-94.

Woodroffe CD. 1995. Response of tide-dominated mangrove shorelines in northern Australia to anticipated sea-level rise. Earth Surface Processes and Landforms 20:65-85.

Woodroffe CD, Murray-Wallace CV. 2012. Sea-level rise and coastal change: the past as a guide to the future. Quaternary Science Reviews 54:4-11.

Woodroffe SA, Long AJ, Punwong P, Selby K, Bryant CL, Marchant R. 2015. Radiocarbon dating of mangrove sediments to constrain Holocene relative sea-level change on Zanzibar in the southwest Indian Ocean. The Holocene 25:820-31. 